\title{
A Retrospective Evaluation of Outcomes of Arteriovenous Fistulas for Hemodialysis
}

\section{Hemodiyaliz Amaçlı Oluşturulan Arteriyovenöz Fistüllerin Akıbetinin Retrospektif Değerlendirilmesi}

\author{
- Mazlum Şahin, ๑ Burcu Bıçakhan, ๑ibrahim Akkoç* \\ University of Health Sciences, Haseki Training and Research Hospital, Clinic of Cardiovascular Surgery, Istanbul, Turkey \\ *University of Health Sciences, Haseki Training and Research Hospital, Clinic of Anesthesiology, Istanbul, Turkey
}

\section{Abstract}

\begin{abstract}
Aim: Chronic renal failure patients require arteriovenous fistulas (AVFs) for hemodialysis purposes. The AVF should be open for a long time and should be easy to access. The aim of our study was to present our experience in AVF patients, to evaluate the complications and success rate.
\end{abstract}

Methods: Medical records of 145 consecutive patients, in whom 160 AVF operations were performed between September 2014 and January 2017 for hemodialysis, were reviewed retrospectively. The nondominant arm was preferred for surgery. AVF surgeries were assessed according to location, complication, and availability.

Results: The mean age of the patients (90 males and 55 females) was $61.8 \pm 6.7$ years. In six-month follow-up, the patency rate was $90 \%$ and the complication rate was $14.4 \%$. Fistula thrombosis was the most common complication.

Conclusion: The main purpose of AVFs is to be open for a long time and to provide sufficient flow. We believe that successful localization and preoperative evaluation will yield successful results.

Keywords: Arteriovenous fistula, hemodialysis, complication
Öz

Amaç: Kronik böbrek yetmezliği bulunan hastalar hemodiyaliz amaçlı arteriyovenöz fistüllere (AVF) gereksinim duyarlar. AVF uzun süreli açık kalabilmeli ve erişimi kolay olmalıdır. Çalışmamııın amacı AVF oluşturulan hastalarımızdaki deneyimlerimizi sunmak, komplikasyonları ve başarı oranını değerlendirmektir.

Yöntemler: Eylül 2014 ile Ocak 2017 tarihleri arasında hemodiyaliz amaçlı 160 AVF ameliyatı yapılan ardışık 145 hastanın tıbbi kayıtları retrospektif olarak değerlendirildi. Dominant olmayan koldan AVF yapıldı. AVF'ler lokalizasyon, komplikasyon, kullanılabilirliğine göre değerlendirildi.

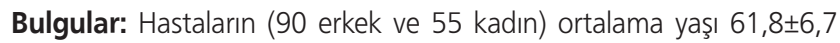
yıldı. Altı aylık takiplerde açıklık oranı \%90, komplikasyon oranı \%14,4 olarak saptandı. Fistül trombozu en sık rastlanılan komplikasyon olarak görüldü.

Sonuç: AVF'lerde temel amaç uzun süre açık kalabilmesi ve yeterli akımı sağlamasıdır. Doğru lokalizasyon ve preoperatif değerlendirme ile başarılı sonuçlar elde edileceğini düşünmekteyiz.

Anahtar Sözcükler: Arteriyovenöz fistül, hemodiyaliz, komplikasyon

\section{Introduction}

Transplantation in renal failure is the permanent solution. However, many of these patients undergo hemodialysis because of the limited number of donors and due to the fact that peritoneal dialysis is restricted because of poor patient hygiene. Hence, creation of arteriovenous fistula (AVF), which can be used for a longer time, for the purpose of hemodialysis is required (1). Functioning of AVFs with less problem increases the duration of hemodialysis treatment in patients. Although AVFs, which were first recommended in 1966 by Brescia et al. (2), has been modified by various technical developments until today, the target has always been the same; i.e., providing a vascular access with high flow, being easy to cannulate and having low complication rate, by arterializing the superficial vein.
Address for Correspondence/Yazışma Adresi: Mazlum Şahin

University of Health Sciences, Haseki Training and Research Hospital, Clinic of Cardiovascular Surgery, İstanbul, Turkey

Phone: +90 5346194374 E-mail: mzlmshn@gmail.com ORCID ID: orcid.org/0000-0001-9630-6634 Received/Geliş Tarihi: 19 June 2017 Accepted/Kabul Tarihi: 23 August 2017
${ }^{\circ}$ Copyright 2018 by The Medical Bulletin of University of Health Sciences Haseki Training and Research Hospital
The Medical Bulletin of Haseki published by Galenos Yayınevi.

'Telif Hakkı 2018 Sağlık Bilimleri Üniversitesi Haseki Eğitim ve Araşıırma Hastanesi Haseki Tıp Bülteni, Galenos Yayınevi tarafından basıımıştır. 
Brescia and Cimino recommended creating an AVF between the radial artery and cephalic vein at the level of the wrist. Today, this classical method is still being performed frequently under the name of "Brescia-Cimino method" (3). The purpose of our study was to evaluate the results and complications of AVF operations performed in our clinic.

\section{Methods}

Medical records of 145 consecutive patients, in whom 160 AVFs were created between September 2014 and January 2017 in the Cardiovascular Surgery Clinic at Haseki Training and Research Hospital, were retrospectively evaluated. Ethical committee approval was not obtained because our study was retrospective. Synthetic graft was not used and fistula was not created in the lower extremities in these patients. A strict attention was paid to preserve the extremity that would undergo AVF surgery and not to use this extremity for any intervention or injection during 10 days prior to the operation. Primarily, the non-dominant arm and distal part of the extremity were preferred. The snuffbox region was not used in these patients.

The procedure was performed after routine measurement of the venous and arterial diameters of the extremities by arterial and venous Doppler ultrasonography. While identifying the regions in order to create a fistula, the regions, for which a central catheter was previously placed or multiple venous interventions were performed previously, were avoided.

AVF was performed with 7/0 polypropylene suture and under local anesthesia. Systemic anticoagulation was performed with heparin at a dose of $100 \mathrm{U} / \mathrm{kg}$ before clamping the artery and the vein. The length of arteriotomy and venotomy was $5 \mathrm{~mm}$ in the wrist and $3 \mathrm{~mm}$ in the antecubital area. In patients with a small venous diameter, the veins were mechanically dilated prior to anastomosis with physiological saline solution infused through $18 \mathrm{G}$ branule by clamping the vein. Thrill felt over the vein after the procedure was considered an adequate procedure (Figure 1).

Antiplatelet or anticoagulant agent was not given to the patients after the procedure. Follow-up was performed at scheduled control visits one week, month, and six month after the procedure.

\section{Surgical Technique}

Patients with suitable anatomical sites and vessels were operated under local anesthesia in the operating room following surgical site preparation and covering. For the forearm, generally longitudinal, and for the antecubital region, a longitudinal incision was applied. The veins were identified; vein angulation and swelling were prevented and the anastomosis was approximated as planned. A venous longitudinal venotomy of 1-2 mm length was performed for the planned anastomosis; $100 \mathrm{U} / \mathrm{kg}$ heparin was administered slowly first, then pressurized with $10 \mathrm{~mL}$ saline using plastic cannula. After confirming venous compliance, the appropriate artery was removed and a longitudinal arteriotomy was performed. Anastomosis was performed side by side with continuous technique with a 7/05 prolene suture. The diameter of the anastomosis was determined not to exceed about 2 times the vein diameter but to be at least $6 \mathrm{~mm}$. The distal part of the vein was ligated and the hooks were released. The surgery was terminated when full filling, pulsation and vibration were detected.

\section{Statistical Analysis}

Data analyses were performed using the GraphPad InStat version 3.1a, (GraphPad Software, San Diego, CA, USA). Continuous variables were expressed as mean \pm standard deviation and categorical variables were expressed as frequency and percentage.

\section{Results}

Of the 145 patients, who underwent AVF surgery between September 2014 and January 2017, 90 (62.07\%)

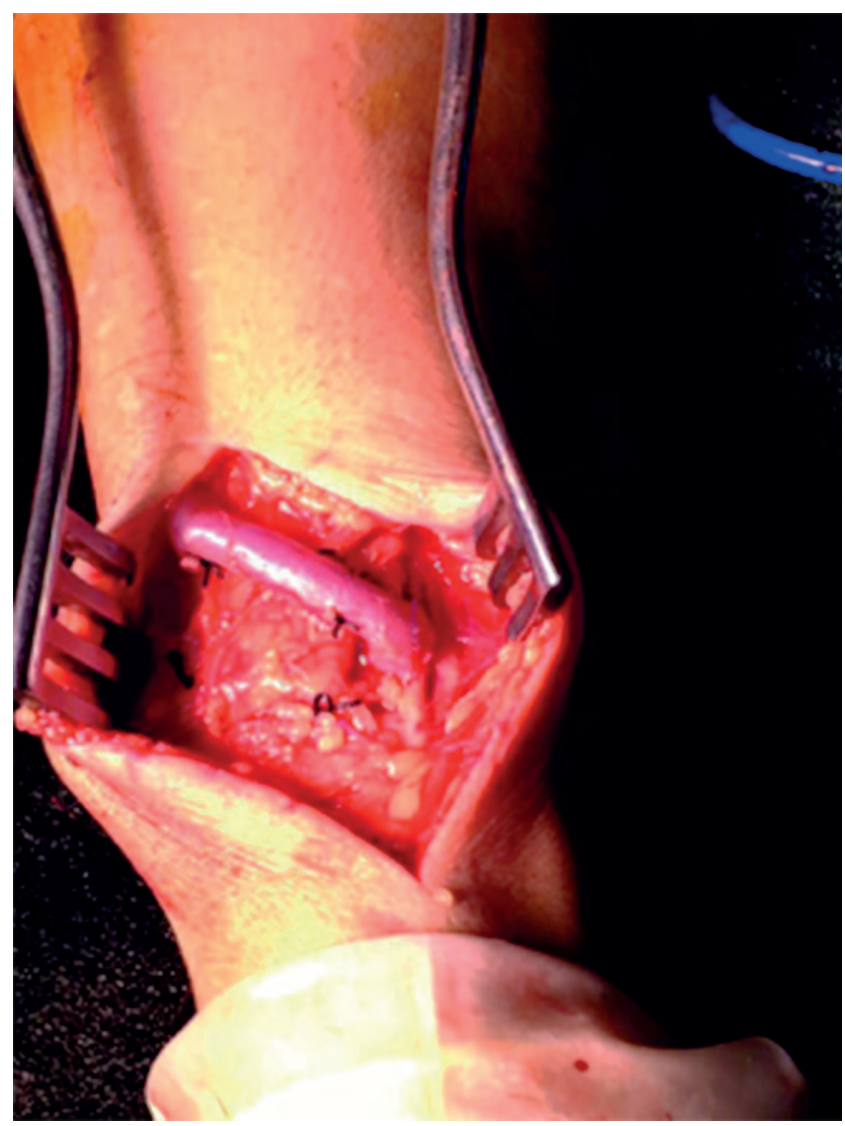

Figure 1. A radiocephalıc arteriovenous fistula 
were male and 55 (37.93\%) were female. The mean age

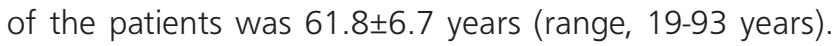
Fifteen patients underwent surgery for the second time. All AVF surgeries $(n=160)$ were performed in the upper extremities. The mean follow-up period was six months.

Of the 160 AVF surgeries, 98 AVFs involved the cephalic vein and radial artery, 49 AVFs cephalic vein and brachial artery, and 13 AVFs involved the basilic vein and brachial artery (Table 1).

Several complications occurred in $21(13.12 \%)$ cases. These complications were thrombosis in $15(9.37 \%)$ cases, bleeding in $3(1.81 \%)$, hematoma in $1(0.62 \%)$, and hand ischemia due to steal syndrome in $2(1.25 \%)$ cases (Table 2 ).

No infection or aneurysm occurred. The patency rate of AVFs was $95 \%$ at the end of the 1 st week and $90.62 \%$ at the end of the $6^{\text {th }}$ month.

Fifteen patients were re-operated due to thrombosis. Thrombectomy was performed first, however, a new AVF was created in the patients in whom success could not be achieved.

\begin{tabular}{|l|l|}
\hline \multicolumn{2}{|l|}{ Table 1. Localization of arteriovenous fistulas } \\
\hline Localization & $\mathbf{n}(\%)$ \\
\hline Radiocephalic & $98(61.25)$ \\
\hline Brachiocephalic & $49(30.62)$ \\
\hline Brachiobasilic & $13(8.12)$ \\
\hline Total & $160(100)$ \\
\hline
\end{tabular}

\begin{tabular}{|l|l|}
\hline $\begin{array}{l}\text { Table 2. Complications observed in the arteriovenous fistula } \\
\text { surgeries }\end{array}$ \\
\hline Complications & $\mathbf{n}(\%)$ \\
\hline Thrombosis & $15(9.37)$ \\
\hline Bleeding & $3(1.81)$ \\
\hline Hand ischemia & $2(1.25)$ \\
\hline Hematoma & $1(0.62)$ \\
\hline Total & $21(13.12)$ \\
\hline
\end{tabular}

\section{Discussion}

An AVF is preferred as the first choice to achieve hemodialysis treatment which improves the quality of life in patients with chronic renal failure (4). Age of the patient, accompanying diseases, and vascular status should be assessed to determine the type of the AVF. An increase in the number of diabetics among patients requiring hemodialysis poses a challenge for nephrologists and vascular surgeons (3). Atherosclerosis together with increased oxidative stress is more widespread and serious in patients with diabetes mellitus (DM) (4-6). Of the patients included in the present study, 43 (46.7\%) patients had concomitant DM.

To determine the type of AVF in patients with chronic renal failure, primarily the non-dominant arm and the most distal part is preferred. The proximal area of the arm should be preserved as much as possible to perform a new AVF in the future (6). The choice of anastomosis technique depends on the status, location, structure, and lumen thickness of the vessels and on the surgeon's technique. Anastomosis technique can be side-to-side, end-to-side, or end-to-end in AVF-native patients. Using a synthetic graft may be another option in AVF surgery. The aim of all these several surgical techniques is to provide a functioning, efficient, and a long-lasting AVF. In the present study, we preferred mostly side-to-side or end-to-side anastomosis technique in AVF involving the wrist (radiocephalic or Brescia-Cimino) and antecubital fossa (brachial artery to cephalic vein).

The factors leading to high patency rate in the present study were as follows: attentive performance during surgical procedure and precise dissection as well as removal of the tissues around the vascular structures that might cause obstruction (5), performing regular and full-thickness suturing by paying attention to the intima not to be cleaved, and routine preoperative evaluation of the venous structures by Doppler ultrasonography. Doppler ultrasonography was performed to evaluate the venous and arterial diameters (should be at least $2.5 \mathrm{~mm}$ and $2.0 \mathrm{~mm}$, respectively) and the absence of intraluminal thrombus.

Some previous studies have determined that the rate of early obstruction is higher in fistulas created at the snuffbox region than in those created at the wrist or a bit proximally to the wrist level (7). In the present study, none of the AVFs was created at the snuffbox region. However, successful AVFs can be created at the anatomical snuffbox (radial fossa) in case distal aspects of the cephalic vein and radial artery are convenient.

High venous pressure unfavorably influences the patency of AVF. The primary cause of this high pressure in the veins is stenosis secondary to previous venous interventions. The rate of subclavian vein stenosis due to central venous catheterization has been reported to be $20 \%-40 \%$ (8). For this reason, in the present study, the regions that were previously exposed to central venous catheterization or venous interventions were not primarily preferred.

Early complications after AVF surgeries include thrombosis, hematoma, hemorrhage, and infection, whereas local complications, such as thrombosis, extremity edema, and extremity ischemia due to arterial steal syndrome, graft infection, aneurysm and pseudoaneurysm 
or systemic complications, such as heart failure due to high fistula flow, can be observed as late complications (9).

AVF thrombosis is the most frequent complication of AVFs both in the early and late phases (9.4\%-38\%) (5). The main causes of early thrombosis include technical failure in anastomosis, using small-diameter vascular structures exposed to pathological alterations due to surgical intervention and renal insufficiency, hypotension, hemoconcentration, increased thrombocyte activation, and compression due to hematoma caused by previous intervention. In the present study, thrombosis developed in $15(9.37 \%)$ cases.

Many studies have demonstrated superior patency of the autogenous fistulas over polytetrafluorethylene (PTFE) or biological grafts. Huber et al. (10) compared autogenous fistulas with those created using PTFE graft and found a significantly higher patency rate in autogenous fistulas. On the other hand, the risk of developing infection ranges from $0 \%$ to $6 \%$ in autogenous fistulas (11). In the present study, none of the patients developed infection; PTFE graft or biological graft was not used in any patient in this study.

Ischemic changes progressing to necrosis may occur in the extremities after AVF surgeries. In the present study, two (1.25\%) patients, in whom AVF was created between the brachial artery and the cephalic vein, developed hand ischemia due to steal syndrome. In these two patients, AVF was closed and then re-created in the other extremity.

\section{Study Limitations}

There are some limitations in our work. First of all, our study was retrospective and the sample included relatively few patients. Finally, the present study has analyzed only short-term outcomes.

\section{Conclusion}

Although there are various methods used to facilitate hemodialysis procedure, AVF surgery remains to be the most commonly used one. We assume that functioning of AVFs for a long-time depends on the patient's vascular structure being convenient, choosing the appropriate anastomosis technique, and eliminating unfavorable iatrogenic effects while using the AVF.

\section{Ethics}

Ethics Committee Approval: Retrospective study. Informed Consent: Retrospective study.
Peer-review: Externally peer-reviewed.

\section{Authorship Contributions}

Surgical and Medical Practices: M.Ş. Concept: B.B. Design: I.A. Data Collection or Processing: I.A. Analysis or Interpretation: B.B. Literature Search: B.B. Writing: M.Ş.

Conflict of Interest: No conflict of interest was declared by the authors.

Financial Disclosure: The authors declared that this study received no financial support.

\section{References}

1. Albers FJ. Causes of hemodialysis access failure. Adv Ren Replace Ther 1994;1:107-18.

2. Brescia MJ, Cimino JE, Appel K, Hurwich BJ. Chronic hemodialysis using venipuncture and a surgically created arteriovenous fistula. N Engl J Med 1966;275:1089-92.

3. Chiti E, Ercolini L, Mancini G, et al. Arteriovenous fistulas for hemodialysis: transposition of the cephalic veins, a personal experience. Minerva Urol Nefrol 1999;51:211-5.

4. Jenkins AM, Buist TA, Glover SD. Medium-term follow-up of forty autogenous vein and forty polytetrafluoroethylene (Gore-Tex) grafts for vascular access. Surgery 1980;88:66772.

5. Akbaş $H$, Kanko $M$, Tekinalp $H$, Bülbül $S$, Alp M. Hemodializ amaçlı arteriyovenöz fistüllerin retrospektif değerlendirilmesi. Türk Göğüs Kalp Damar Cer Derg 2000;8:638-40.

6. Simoni G, Bonalumi U, Civalleri D, Decian F, Bartoli FG. End-toend arteriovenous fistula for chronic haemodialysis: 11 years' experience. Cardiovasc Surg 1994;2:63-6.

7. Demirkılıç U, Kuralay E, Yılmaz AT. Snuffbox bölgesinde farklı anastomoz teknikleri ile yapılan arteriyovenöz fistüllerin karşılaştırılması. Damar Cer Derg 1997;6:24-30.

8. Taşdemir K, Kahraman C, Ünlü i. Kronik böbrek yetmezlikli hastalarda oluşturulan arteriyovenöz fistüller için uygulanan cerrahi teknikler ve sonuçları. Türk Nefroloji Diyaliz ve Transplantasyon Dergisi 2009;18:10-4.

9. Konner K, Hulbert-Shearon TE, Roys EC, Port FK. Tailoring the initial vascular access for dialysis patients. Kidney Int 2002;62:329-38.

10. Huber TS, Carter JW, Carter RL, Seeger JM. Patency of autogenous and polytetrafluoroethylene upper extremity arteriovenous hemodialysis accesses: a systematic review. J Vasc Surg 2003;38:1005-11.

11. Gökșin I, Baltalarlı A, Önem G, et al. T: Arteriyovenöz fistül operasyonları. Erken ve geç dönemde revizyon gerektiren komplikasyonlar. Turkish J Thorac Cardiovasc Surg 2004;12:180-3. 